\title{
How to obtain and isolate equine sternal bone marrow mononuclear cells with limited resources
}

\author{
Cómo obtener y aislar células mononucleares de médula ósea esternal equina \\ con recursos limitados
}

\author{
F Corrêa ${ }^{\mathrm{a}}$, C Borlone ${ }^{\mathrm{a}}$, F Wittwera ${ }^{\mathrm{a}}$, H Bustamante ${ }^{\mathrm{a}}$, A Müller ${ }^{\mathrm{a}}$, A Ramírez ${ }^{\mathrm{b}}$, B Menarim ${ }^{\mathrm{a}}$ \\ ${ }^{a}$ Instituto de Ciencias Clínicas Veterinarias, Facultad de Ciencias Veterinarias, Universidad Austral de Chile, Valdivia, Chile. \\ bInstituto de Ciencia Animal, Facultad de Ciencias Veterinarias, Universidad Austral de Chile, Valdivia, Chile.
}

\begin{abstract}
RESUMEN
Las lesiones musculoesqueléticas en caballos son frecuentes y conllevan a pérdidas económicas substanciales. La fracción de células mononucleares originadas de la médula ósea, porción que contiene células troncomesenquimales, ha sido aplicada exitosamente para mejorar la reparación de lesiones musculoesqueléticas en esta especie. Diversos reportes sobre cómo obtener y aislar productos de origen medular han sido descritos; sin embargo, esos consideran la utilización de laboratorios altamente equipados. El objetivo del presente manuscrito es demostrar a médicos veterinarios que obtener y aislar células mononucleares de medula ósea esternal para uso clínico es posible mediante equipos básicos de laboratorio. Muestras de médula ósea de 10 caballos fueron obtenidas a partir de la $5^{\mathrm{a}}$ esternebra en jeringas de $60 \mathrm{~mL}$ conteniendo heparina y DPBS. Las muestras fueron procesadas dentro de $1 \mathrm{~h}$ posterior a la recolección usando instrumentos habitualmente encontrados en la mayoría de las clínicas equinas. Luego del aislamiento de la fracción mononuclear, la concentración y viabilidad celular de esta fueron determinadas por recuento en cámara de Neubauer ${ }^{\circledR}$. El concentrado final de $1 \mathrm{~mL}$ presentó concentración de células mononucleares (media $\pm \mathrm{DE}$ ) y un porcentaje de viabilidad de $190 \pm 54$ x $10^{6}$ y $98 \pm 1,2 \%$, respectivamente. No se observó contaminación en las muestras obtenidas y los caballos tratados con el concentrado medular usando esta técnica no presentaron complicaciones clínicas. La aspiración y el procesamiento de médula ósea esternal equina usando la técnica descrita es un método de bajo costo y seguro para obtener células mononucleares para terapias celulares.
\end{abstract}

Palabras clave: célula tronco, caballo, musculoesquelético, terapia regenerativa.

\section{SUMMARY}

Musculoskeletal injuries in horses are very frequent and lead to substantial financial losses. Bone marrow mononuclear cells (BMMNCs), the fraction of bone marrow containing mesenchymal stem cells, have been successfully employed to enhance healing of tendon, ligament and articular injuries in this specie. Many descriptions of how to harvest equine BM and isolate BMMNCs have been described; however, reported protocols consider fully equipped and costly laboratory facilities. The aim of this manuscript is to demonstrate to veterinary practitioners that obtaining and effective isolating equine BMMNCs for clinical use is possible with basic laboratory equipment. BM samples of 10 horses were collected from the $5^{\text {th }}$ sternebra into $60 \mathrm{~mL}$ syringes containing heparin and Dulbecco's Phosphate-Buffered Saline (DPBS) using equipment that can be found in most equine clinics. Further, samples were centrifuged by density gradient for BMMNCs isolation within $1 \mathrm{~h}$ after collection. Concentration and cell viability was determined by both direct counting on a Neubauer ${ }^{\circledR}$ chamber and epifluorescence analysis. Harvesting and isolation was achieved for all horses with no restrictions. The final $1 \mathrm{~mL}$ concentrate considered total number of BMMNCs (mean \pm SD) and percentage of cell viability amongst isolates were $190 \pm 54 \times 10^{6}$ and $98 \pm 1.2 \%$, respectively. Contamination was not observed in obtained samples and horses treated with BMMNCs using this technique did not present any clinical complications. Aspiration and processing of equine sternal BM using the described technique is a low cost and reliable method to obtain BMMNCs for cell based therapies.

Key words: cell separation, horse, musculoskeletal, regenerative medicine.

\section{INTRODUCTION}

Lameness due to musculoskeletal injuries is the most frequent problem in the equine industry and leads to substantial financial losses related to treatment, resting periods, recurrence and poor performance in athlete equines (Dyson 2004). Most of these injuries are related to musculoskeletal structures, such as joints, tendons and ligaments, which

Accepted: 28.11.2013.

* Hospital Veterinario, Fundo Teja Norte s/n, Universidad Austral de Chile, Isla Teja, Valdivia, Chile; brunomenarim@uach.cl generally respond to conventional therapies with scar tissue formation leading to chronic and/or degenerative processes, ending in a high risk of recurrence. The application of regenerative medicine for the treatment of musculoskeletal diseases has widely increased in veterinary medicine due to the perspective of higher successful rates (Stewart and Stewart 2011, Owens et al 2011). The most common related techniques consider the application of platelet rich plasma (PRP) and/or mesenchymal stem cells (MSCs). The main sources of MSCs in the clinical setting are: bone marrow (BM), adipose tissue and umbilical cord blood (Taylor and Clegg 2011). From BM, there are two main products that 
are being currently applied for the treatment of orthopedic injuries in the horse: bone marrow mononuclear cell fraction (BMMNCs), which comprise some hematopoietic progenitor cells, MSCs and monocytes, which can be readily isolated and injected into the lesion; on the other hand, there is the use of cultivated MSCs derived from the mononuclear cells (MNCs) fraction of BM. Both have demonstrated to enhance the repair of soft tissue injuries in horses (Smith et al 2003, Oliveira 2008, Crovace et al 2010), nonetheless, all the described protocols require access to fully equipped and costly laboratory facilities. Besides, obtaining a pure fraction of cultivated MSCs also demands longer time (2-3 weeks) (Fortier and Smith 2008, Kol et al 2013) and higher costs related to cell culture (Owens et al 2011). This study aims to demonstrate to equine and other veterinary practitioners that obtaining and isolating BMMNCs from horses is a simple procedure and can be performed with basic laboratory equipment.

\section{MATERIAL AND METHODS}

All necessary equipment should be assembled before beginning the procedure (table 1). There is a variety of needles available to aspirate BM in the horse. The authors prefer to use an $11 \mathrm{G}$ x $10 \mathrm{~cm}$ Komiyashiki reusable needle (figure 1a) for this purpose.

\section{HORSES}

In order to demonstrate the applicability of this technique, the authors performed this procedure in 10 healthy crossbred adult horses ranging between 5-17 years of age.

\section{BONE MARROW ASPIRATION}

The horses were appropriately restrained using stocks and sedation according to their temperament (Taylor and Clegg 2011). The administration of xylazine ${ }^{1}(0.5-1 \mathrm{mg} /$ $\mathrm{kg}, \mathrm{IV}$ ) provides sufficient restraint for most adult horses. Its combination with an opiate (butorphanol $0.02 \mathrm{mg} / \mathrm{kg}$ IV or morphine $0.1 \mathrm{mg} / \mathrm{kg} \mathrm{IV}$ ) or the use of detomidine $(0.02 \mathrm{mg} / \mathrm{kg}, \mathrm{IV})$ (Taylor and Clarke 2007) is recommended for patients that require stronger sedation (Kasashima $e t$ al 2011). A $10 \times 10 \mathrm{~cm}$ wide band overlying the ventral sternum is clipped and scrubbed clean with $2 \%$ clorhexidine detergent and $70 \%$ alcohol. The sternum was palpated on ventral midline in the cranial thorax at the level of the elbows and the $5^{\text {th }}$ sternebra was located (Kasashima et al 2011). Local anaesthetic $(10 \mathrm{~mL}, 2 \%$ mepivicaine solution) was injected at the predicted aspiration area and scrubbed a final time.

Prior to aspiration, one $60 \mathrm{~mL}$ syringe was aseptically preloaded with $15000 \mathrm{IU}$ of heparin $+10 \mathrm{~mL}$ (DPBS) and preserved sterile. An $11 \mathrm{G}$ x $10 \mathrm{~cm}$ Komiyashiki needle

1 König Lab., Montevideo, Uruguay.
Table 1. Equipment and supplies required to harvest bone marrow from an adult horse and isolate bone marrow mononuclear cells.

Equipos y materiales requeridos para obtener médula ósea de un caballo adulto y aislar células mononucleares de medula ósea esternal.

Drugs for chemical restrain

Clippers

Surgical prep supplies

Sterile gloves

Komiyashiki needle ${ }^{2}$

Mepivacaine $^{3}$

Sterile $60 \mathrm{~mL}$ syringe containing $15000 \mathrm{IU}$ sodium heparin $(3 \mathrm{~mL})$

Plastic Petri dish

Sterile $4 \times 4$ gauze pads

Pasteur pipette / Sterile IV catheter 14Gx2"

Latex gloves

Dulbecco's Phosphate-Buffered Saline (DPBS) ${ }^{4}$

Falcon ${ }^{\circledR 5} 15 \mathrm{ml}$ tubes

Ficoll ${ }^{\circledR 6}$

Swinging bucket centrifuge

was introduced perpendicularly through the anaesthetised area and moved forward until it contacted the middle length of the ventral midline surface of the $5^{\text {th }}$ sternebra (figure $1 \mathrm{~b}, 1 \mathrm{c}$ ). The index finger was placed no more than $2 \mathrm{~cm}$ behind the tip of the needle, which was gradually moved forward using rotating movements until it was firmly seated into the bone to a depth of $1-2 \mathrm{~cm}$ into the medullar cavity (Sellon 2006, Taylor and Clegg 2011, Kasashima et al 2011). The stylet moved forward removed from the needle, the $60 \mathrm{~mL}$ syringe moved forward attached to its hub and gentle pulsatile aspiration was applied to obtain the sample. The sample was carefully mixed by several inversions to ensure an adequate combination of heparin and marrow that prevents clotting. One drop of the $60 \mathrm{~mL}$ syringe content was placed on a clear Petri dish and grossly examined for evidence of small, grayish marrow spikes and fat particles that adhere loosely to the plastic (Taylor and Clegg 2011). If spikes and fat were observed, it was likely that a sample of adequate origin had been obtained, therefore the needle could be removed and sterile gauze was held over the area with light pressure to facilitate haemostasis. The sample was transported to the on-site laboratory in cooling recipients at $5^{\circ}$ to $8{ }^{\circ} \mathrm{C}$ (same as used for semen transportation). Generally, between 15 to $20 \mathrm{~mL}$ are harvested per aspirate. If the marrow sample obtained in the first attempt is not enough, needle placement should be altered to the adjacent sternebra and the procedure should be repeated.

2 Fremiqsur Ltda., Temuco, Chile.

3 Pfizer, New York, USA.

4 Invitrogen Canada Inc., Burlington, Ontario, Canada.

5 BD Biosciences, Santiago, Chile.

6 Sigma-Aldrich, Santiago, Chile. 
Even though objective confirmation of sample's origin is not essential for experienced practitioners, a stained smear can be processed. For this purpose, marrow particles are collected with pipette and placed on one end of a glass slide, which is then held vertically. Particles tend to stick to the slide while blood runs off. A second glass slide was placed across the area of particle adherence, perpendicular to the first slide. After marrow spreads between the slides, they were pulled apart in the horizontal plane (Reagan et al 2011). The prepared slide was then dried quickly by waving it rapidly in the air and stained using a Romanowsky-type stain (Wright-Giemsa or Dif Quik) (Sellon 2006, Reagan et al 2011). The stained smear was scanned microscopically using a 10X and 40X objectives to ensure the presence of marrow tissue, megakaryocytes and hematopoietic precursor cells (figure $3 \mathrm{a}, 3 \mathrm{~b}$ ).

\section{MONONUCLEAR CELLS ISOLATION}

The sample should be initially filtered in a transfusion set of $200 \mu \mathrm{m}$ in order to remove bone fragments and cell clumps (figure $2 a, 2 b$ ), and then gently layered over $2.5 \mathrm{~mL}$ Ficoll ${ }^{\circledR}$ solution in sterile $15 \mathrm{~mL} \mathrm{Falcon}^{\circledR}$ tube (Bourzac et al 2010). The tube was centrifuged at $500 \mathrm{~g}$ for 30 minutes at $5^{\circ} \mathrm{C}$. After centrifugation, the supernatant plasma is carefully collected by aspiration with a sterile Pasteur pipette, and discarded, avoiding drag cells from the sediment. The clear layer containing the MNCs and Ficoll ${ }^{\circledR}$ (figure 2c, 2d), was then transferred to another sterile Falcon ${ }^{\circledR}$ tube which was completed with DPBS and centrifuged at $300 \mathrm{~g}$ for 10 minutes at $5^{\circ} \mathrm{C}$. Then, $80 \%$ of the supernatant was removed and the remnant completed with DPBS followed by a last centrifugation at $300 \mathrm{~g}$ for 10 minutes at $5{ }^{\circ} \mathrm{C}$, to remove the excess of Ficoll ${ }^{\circledR}$. Most of the supernatant $(\approx 90 \%)$ was discarded and an aliquot of 8-10 $\mu \mathrm{l}$ of the isolated cell suspension was subjected to a cell count and viability determination.

\section{TOTAL CELL COUNT AND VIABILITY TEST}

Whereas not mandatory, in order to access the sample quality, the concentration of isolated MNCs in this study was determined using a Neubauer ${ }^{\circledR}$ chamber or a conventional blood cell automated counter. Viability can be confirmed through the application of a Dye Exclusion Test using trypan blue in a Neubauer ${ }^{\circledR}$ chamber, a simple and precise technique (Kerr 2002). A Gram staining was performed on the samples of this study in order to evaluate bacterial contamination.

\section{FACILITIES/WORKING ENVIRONMENT}

Other reported protocols for the isolation of BM products consider the use of laminar flow tissue culture hood which are sterilised with $70 \%$ ethanol or isopropanol before and after use (Helgason 2004, Taylor and Clegg 2011), however, the authors proposed that it can be replaced by good sterile technique in a clean laboratory environment when handling and processing the samples. These involve decontamination of all work surfaces with the previously mentioned products and sterilization of required material. The worker should wear a clean lab coat and latex gloves that cover all exposed skin that gets in contact with the samples. It isimportant that surfaces that are in direct contact with the samples are not touched, such as tube taps, hubs of syringes and needle tips.

\section{RESULTS AND DISCUSSION}

Harvesting and isolation was achieved for the 10 horses with no restrictions using the previously described technique. The total number of BMMNCs (mean $\pm \mathrm{SD}$ ) and percentage of cell viability observed was $190 \pm 54 \times 10^{6}$ and $98 \pm 1.2 \%$, respectively (table 2 ). According to Gram staining technique, no evidence of bacterial contamination was observed.

MSCs in horses are commonly retrieved from BM, adipose tissue and umbilical cord blood samples. The sternum is the most commonly used site for aspiration of mesenchymal stem cells derived from equine bone marrow (Taylor and Clegg 2011) and the $5^{\text {th }}$ sternebra has been reported to be most safe of sites, as it has the largest dorsoventral span and is cranial to the apex of the heart (Kasashima et al 2011). Other sites for BM aspiration in the horse include the tuber coxae, tibia, ribs and humerus (Sellon 2006, Taylor and Clegg 2011). However, in the author's experience, the sternum should be the site of choice to perform BM aspiration in horses because its safer for the practitioner and the patient, and retrieve a larger amount of sample.

Reported complications of sternal BM sampling in horses include cardiac puncture and nonfatal pneumopericardium (Taylor and Clegg 2011). No complications were observed in the 10 horses of this study. That risk can be minimised

Table 2. Concentration per $\mathrm{mL}$ and viability of equine mononuclear cells obtained from bone marrow samples of 10 horses. Concentración por $\mathrm{mL}$ y viabilidad de células mononucleares obtenidas a partir de muestras de médula ósea de 10 caballos.

\begin{tabular}{lccccccccccc}
\hline \multicolumn{1}{c}{ Horse } & 1 & 2 & 3 & 4 & 5 & 6 & 7 & 8 & 9 & 10 & Mean \\
\hline Cell concentration $\left(\mathrm{x} 10^{6}\right)$ & 272 & 180 & 147 & 84 & 186 & 179 & 256 & 169 & 213 & 215 & 190 \\
Cell viability (\%) & 96 & 97 & 97 & 99 & 97 & 99 & 99 & 98 & 99 & 99 & 98 \\
\hline
\end{tabular}




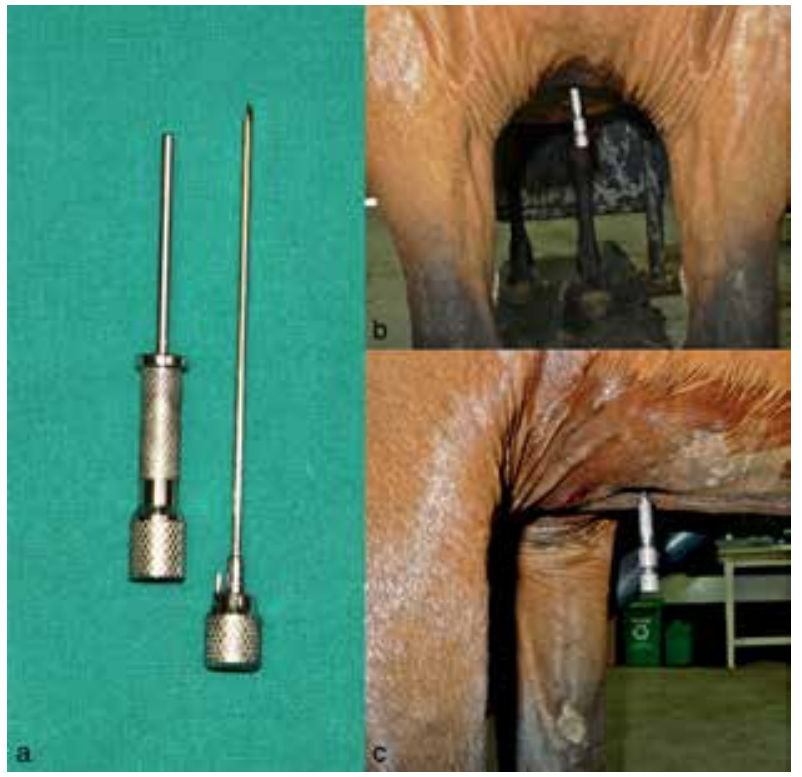

Figure 1. Komiyashiki reusable needle for aspiration of equine bone marrow (a). Placement of the needle over the $5^{\text {th }}$ sternebra on the ventral surface of the sternum (cranial view) (b). Lateral view (c).

Aguja Komiyashiki reusable para la aspiración de médula ósea equina (a). Posicionamiento de la aguja sobre la $5^{\mathrm{a}}$ esternebra en la superficie ventral del esternón (vista craneal) (b). Vista lateral (c).

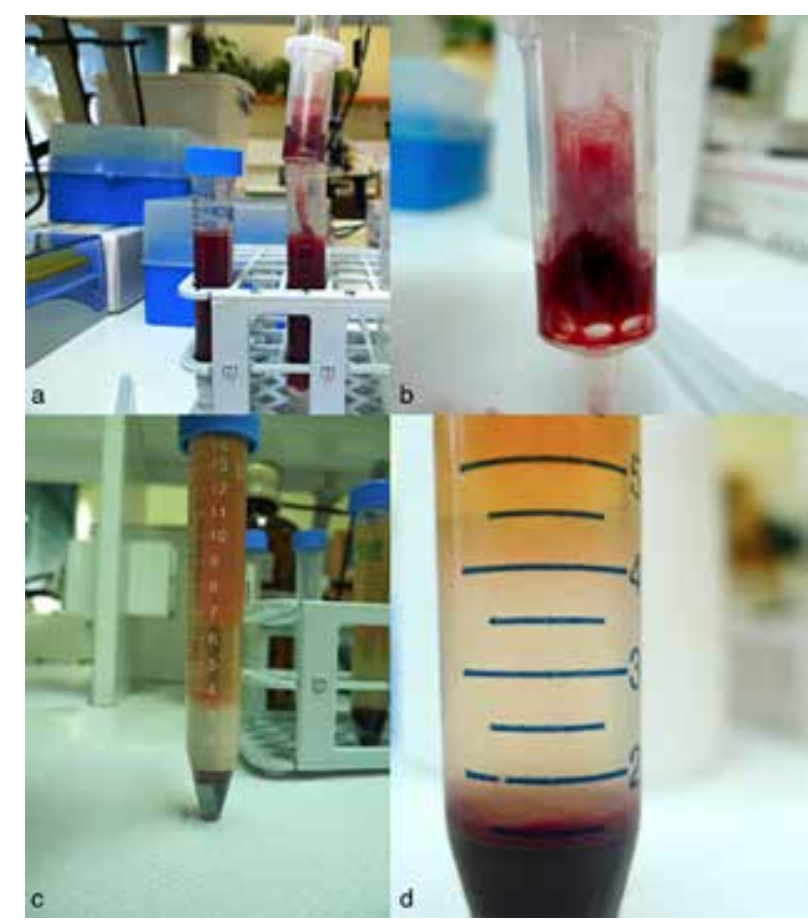

Figure 2. Sample of bone marrow layered over $2.5 \mathrm{~mL} \mathrm{Ficoll}^{\circledR}$ solution in a sterile Falcon ${ }^{\circledR}$ tube (a). Fragments and cell clumps filtered in a transfusion equipment of $200 \mu \mathrm{m}$ (b). Separation of mononucleated cells by density centrifugation in Ficoll ${ }^{\circledR}$ (c). Close-up of the mononuclear cells layer (d).

Muestra de médula ósea depositada sobre $2,5 \mathrm{~mL}$ de solución Ficoll ${ }^{\circledR}$ en un tubo Falcon ${ }^{\circledR}$ estéril (a). Fragmentos y agregados celulares filtrados en un equipo de transfusión de $200 \mu \mathrm{m}$ (b). Separación de las células nucleadas por densidad de centrifugación en Ficoll ${ }^{\circledR}(\mathrm{c})$. Acercamiento a la capa de células mononucleares (d).

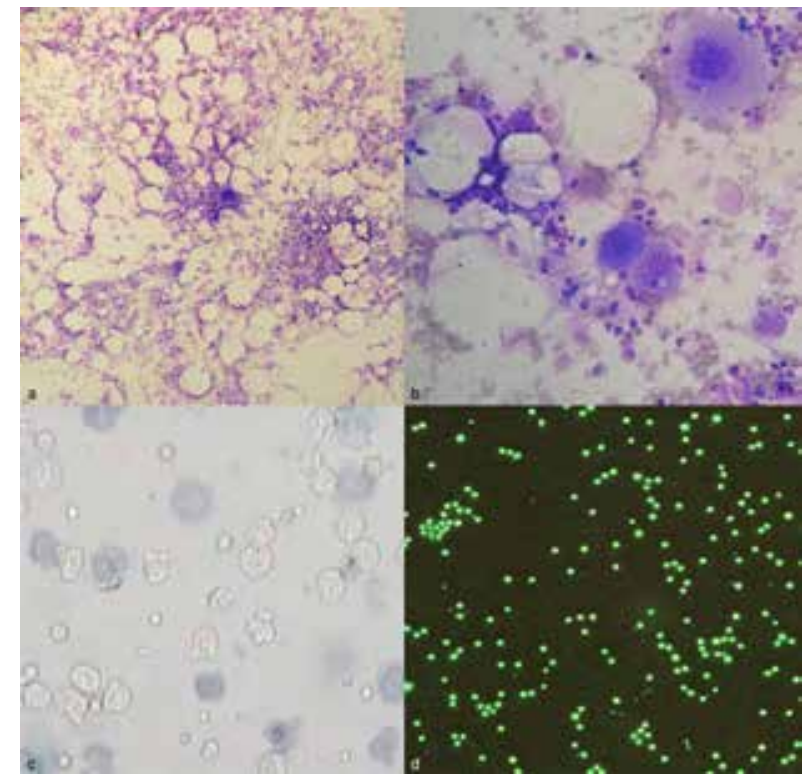

Figure 3. Microscopic image of a normal bone marrow aspirate from a horse showing a large number of mononucleated cells and one megakaryocyte (10x) (a). Microscopic image of a normal bone marrow aspirate from a horse showing a few number of mononucleated cells and three megakaryocytes in different stages of differentiation (40x) (b). Dye Exclusion Test using trypan blue to assess the sample quality (figure adapted from Barreira 2005) (c). Alive mononucleated cells assessed thorough ephifluorescent microscopy using ethidium bromide/acridine orange staining test (40x) (d).

Imagen microscópica de aspirado medular normal de un caballo con una gran cantidad de células mononucleadas y un megacariocito (10x) (a). Imagen microscópica de aspirado medular normal de un caballo con escaso número de células mononucleadas y tres megacariocitos en diferentes estados de diferenciación (40x) (b). Test de tinción usando azul de tripan para analizar la calidad de la muestra (figura adaptada de Barreira 2005) (c). Células mononucleadas vivas analizadas mediante microscopia epifluorescente usando test de tinción con bromuro de etidio/naranja de acridina (40x) (d).

by carefully placing the needle at right angles $\left(90^{\circ}\right)$ to the surface of the sternebra and closely monitoring and controlling depth (no more than $2 \mathrm{~cm}$ ) of penetration of the needle into the bone during the procedure (Sellon 2006, Kasashima et al 2011). The authors consider that the use of a Komiyashiki needle with the reported length is unlikely to penetrate the thorax. Infection of BM or subcutaneous tissues is a possible concern after BM collection; however, the risk seems to be minimal if strict sterile technique is maintained, and it has never been observed by the authors. Hemorrhage is a potential complication, especially in horses with coagulation abnormalities such as severe thrombocytopenia. Direct pressure at the puncture site is sufficient to control hemorrhage in most horses (Sellon 2006, Taylor and Clegg 2011). If marrow particles are not observed or if the number of mononucleated cells is low, re-aspiration should be considered. Although viscosity of the sample can be suggestive of marrow origin, the 
authors do not consider it to be a criterion to evaluate the origin of the sample.

The addition of anticoagulant and DPBS to the syringes used for BM aspiration helps to prevent clot formation. Although the reviewed literature describes the use of sodium heparin as an anticoagulant for the obtention of BM for cell based therapies (Bourzac et al 2010, Taylor and Clegg 2011, Kasashima et al 2011), the authors could not find reported evidence on the advantage or adversity of its use over sodium citrate for horses.

Although collection of 50-60 mL of BM from the sternum of the horse has been reported (Arnhold et al 2007, Fortier and Smith 2008), the sample might contain blood from peripheral circulation since large volumes are unlikely to be obtained solely from one sternebra. Initial results from a MNCs concentration study from the authors suggest the need to obtain at least $15 \mathrm{~mL}$ of BM aspirate when the sample is intended to be used as a BMMNCs (Corrêa et al 2012).

The use of Pasteur's pipette can be replaced by a sterile disposable IV catheter $14 \mathrm{G}$ x 2" attached to a $60 \mathrm{~mL}$ sterile plastic syringe. These are commonly used at any large animal clinic and should be available to the equine practitioner.

When layering the sample over Ficoll ${ }^{\circledR}$, care should be taken to do not mix both components, otherwise, low MNCs concentration can be the consequence, as the Ficoll ${ }^{\circledR}$ layer acts as a density filter.

The authors have performed direct cell counting on a Neubauer ${ }^{\circledR}$ chamber and viability through a dye exclusion test. Epifluorescent microscopy in a digital automated counter (Sperm Class Analyzer ${ }^{\circledR}$ ) using ethidium bromide/ acridine orange staining were also performed and no differences were observed (data not shown). Data regarding MNCs concentration and cell viability obtained with the described method were corroborated with the results of previous investigations (Bourzac et al 2010).

Any cell isolation method can be affected by bacterial or fungal contamination (Taylor and Clegg 2011). It is usually easily identified in cell culture bottles as cells begin to grow slower, the color of the culture medium changes from red to orange/yellow, and fungal hyphae or bacteria are readily identified under phase-contrast microscopy (Taylor and Clegg 2011). During the isolation process, such alterations are not observed because the procedure does not take more than 1 hour. The use of laminar flow hood to reduce risk of contamination is advised, however it does not ensure septic complications will not happen. Besides, in this project Gram staining, an important tool in microbiology (Beveridge 2001, Su RJ and Pei 2011), resulted negative for all samples suggesting the absence of $\mathrm{Gram}^{+}$and $\mathrm{Gram}^{-}$bacterial contamination. Gram staining plays an important role in the rapid presumptive diagnosis, quality evaluation and antimicrobial management of clinical samples in facilities were no cell culture is available $(\mathrm{Su}$ R-J and Pei 2011).
The application of complete BM in tendon and ligament injuries has also been reported as a treatment just after collection, with no septic complications (Herthel 2001). Although not mandatory, the suspension of BMMNCs before injection can be done in cell culture medium which contains antibiotics and anti-fungal, as well the horse can receive antibiotics and cells suspended in autologous plasma.

In 8 cases the BMMNCs were used to treat tendon and/ or ligament injuries. Horses treated with samples obtained using this technique did not present any kind of clinical complications. This suggests that an aseptic technique can be an effective method to obtain these cells for tendon and ligament injury treatment. No observations were reported on the obtention and isolation of the BMMNCs.

Although BMMNCs hold great promise for future cellbased therapeutic strategies and indeed are currently being used on the treatment of several types of equine athlete's and other species musculoskeletal injuries in other species, further studies on the availability to apply the previously described technique to treat joint diseases are required.

The results of this study confirmed that aspiration of BM from the sternum and BMMNCs isolation in the horse using the described technique is a cheap and reliable method to obtain MNCs for cell based therapies to treat equine tendon and ligament injuries.

\section{ACKNOWLEDGEMENTS}

The authors would like to thank the collaboration of Pablo Strobel (BS), Verónica Arnés (BS) and Atilio Delgado for their technical assistance.

\section{REFERENCES}

Arnhold SJ, I Goletz, H Klein. 2007. Isolation and characterization of bone marrow-derived equine mesenchymal stem cells. Am J Vet Res 68, 1095-1105.

Barreira APB. 2005. Implante autólogo de células mesenquimais no tratamento de tendinites induzidas experimentalmente em equinos: avaliaçao clínica, ultrassonográfica, histopatológica e inmunoistoquímica. Dissertaçao Doutorado, Facultade de Medicina Veterinaria e Zootecnia, Universidade Estadual Paulista, Botucatu, Brasil.

Beveridge TJ. 2001. Use of the gram stain in microbiology. Biotech Histochem 76, 111-118.

Bourzac C, LC Smith, P Vincent, G Beauchamp, JP Lavoie, S Laverty. 2010. Isolation of equine bone marrow-derived mesenchymal stem cells: a comparison between three protocols. Equine Vet J42, 519-527.

Corrêa F, J Galecio, H Bustamante, F Wittwer, A Ramírez, B Menarim. 2012. Mononuclear cells concentrations in fractioned samples of bone marrow aspirate of horse sternum. Vet Clin Pathol 41, 46-47.

Crovace A, L Lacitignola, G Rossi, E Francioso. 2010. Histological and immunohistochemical evaluation of autologous cultured bone marrow mesenchymal stem cells and bone marrow mononuclear cells in collagenase induced tendonitis of equine superficial digital flexor tendon. Vet Med Int 2010, 250978.

Dyson SJ. 2004. Medical management of superficial digital flexor tendonitis: a comparative study in 219 horses (1992-2000). Equine Vet J 36, 415-419.

Fortier LA, RKW Smith. 2008. Regenerative medicine for tendinous and ligamentous injuries of sport horses. Vet Clin Equine 24, 191-201.

Helgason CD. 2004. Culture of primary adherent cells and a continuously growing nonadherent cell line. In: Helgason CD, Miller CL (eds). 
Methods in Molecular Biology: Basic Cell Culture Protocols, $3^{\text {rd }}$ ed. Totowa, Humana Press Inc, NJ, USA, Pp 1-12.

Herthel DJ. 2001. Enhanced suspensory ligament healing in 100 horses by stem cells and other bone marrow components. Proceedings of the American Association of Equine Practitioners, San Diego, USA, Pp 319-321.

Kasashima Y, T Ueno, A Tomita, AE Goodship, RK Smith. 2011. Optimization of bone marrow aspiration from the equine sternum for the safe recovery of mesenchymal stem cells. Equine Vet J43, 288-294.

Kerr MG. 2002. Clinical biochemistry and hematology. In: Kerr MG (ed). Veterinary Laboratory Medicine. $2^{\text {nd }}$ ed. Blackwell Science Ltd, Iowa, USA, Pp 275-306.

Kol A, NJ Walker, LD Galuppo, KC Clark, S Buerchler, A Bernanke, DL Borjesson. 2013. Autologous point-of-care cellular therapies variably induce equine mesenchymal stem cell migration, proliferation and cytokine expression. Equine Vet J 45, 193-198.

Oliveira PGG. 2008. Implante autólogo de células mononucleares provenientes de medula óssea no tratamento de tendinites induzidas experimentalmente em equinos: avaliação a longo prazo-120 días. Dissertação de Mestrado, Faculdade de Medicina Veterinária e Zootecnia, Universidade Estadual Paulista, Botucatu, SP, Brasil.

Owens SD, J Burges, JL Johns, DD Carrade, LD Galuppo, F Librach, DL Borjesson. 2011. Processing of equine bone marrow using the automated MarrowXpress System: RBC depletion, volume reduction, and mononuclear cell recovery. Vet Clin Pathol 40, 444-449.

Reagan WJ, A Irizarry-Rovira, F Poitout-Belissent, A Provencher Bolliger, K Ramaiah, G Travlos, D Walker, D Bounous, D Walter. 2011. Best practices for evaluation of bone marrow in nonclinical toxicity studies. Vet Clin Pathol 40, 119-135.

Sellon DC. 2006. How to obtain a diagnostic bone marrow sample from the sternum of an adult horse. Proceedings of the American Association of Equine Practitioners 52, 621-625.

Smith RK, M Korda, GW Blunn, AE Goodship. 2003. Isolation and implantation of autologous equine mesenchymal stem cells from bone marrow into the superficial digital flexor tendon as a potential novel treatment. Equine Vet J 35, 99-102.

Stewart MC, AA Stewart. 2011. Mesenchymal stem cells: characteristics, sources, and mechanisms of action. Vet Clin North Am Equine Pract 27, 243-261.

Su RJ, W Pei. 2011. Role of Gram stain in microbiological laboratories with limited resources. Rev Med Microbiol 22, 41-44.

Taylor PM, KW Clarke. 2007. Sedation and premedication. In: Taylor PM, Clarke KW (eds). Handbook of Equine Anesthesia. $2^{\text {nd }}$ ed. Saunders, Philadelphia, USA, Pp 17-31.

Taylor SE, PD Clegg. 2011. Collection and propagation methods for mesenchymal stromal cells. Vet Clin North Am Equine Pract 27, 263-274. 